\title{
THE
}

\section{The Minimum Wage, Bargaining Power, and the Top Income Share}

Liam C. Malloy

University of Rhode Island, Imalloy@uri.edu

Follow this and additional works at: https://digitalcommons.uri.edu/ecn_facpubs

The University of Rhode Island Faculty have made this article openly available.

Please let us know how Open Access to this research benefits you.

This is a pre-publication author manuscript of the final, published article.

Terms of Use

This article is made available under the terms and conditions applicable towards Open Access

Policy Articles, as set forth in our Terms of Use.

\section{Citation/Publisher Attribution}

Malloy, L. C. (2016, March). The minimum wage, bargaining power, and the top income share. In Forum for Social Economics (pp. 1-24). Routledge.

Available at: https://doi.org/10.1080/07360932.2016.1155468

This Article is brought to you for free and open access by the Economics at DigitalCommons@URI. It has been accepted for inclusion in Economics Faculty Publications by an authorized administrator of DigitalCommons@URI. For more information, please contact digitalcommons-group@uri.edu. 
The Minimum Wage, Bargaining Power, and the Top Income Share

\author{
By Liam C. Malloy
}

Abstract

Much of the argument in support of the minimum wage is its ability to lift workers out of poverty. But the minimum wage also has the potential to influence the relative bargaining power between (non-union) workers and firms and historically this was one of its main purposes. In this paper we review how the minimum wage can improve workers' bargaining position. We use a state-level panel data set that exploits differences in the minimum wage at the state level to show that higher minimum wages, along with unionization rates and higher top marginal tax rates, are successful in reducing overall income inequality, mainly by reducing the share of income going to the top 1 percent of the income distribution. 
Key words: Minimum wage, inequality, bargaining power, poverty

JEL Codes: D6, J3, J5, K3 


\section{Introduction}

The federal minimum wage was first enacted as part of the Fair Labor Standards Act (FLSA) in 1938 and has been increased incrementally since then. The real federal minimum wage hit a high in 1968 at almost $\$ 11$ compared to $\$ 7.25$ today (both in 2015 dollars). However, many states since the late 1960 s have raised their minimum wage above the federal minimum. Much of the argument for raising the minimum wage focuses on paying minimum wage workers a living wage and lifting working Americans out of poverty (Card and Krueger 1995, Addison and Blackburn 1999, Morgan and Kickham 2001, etc. Dube 2013 provides a review). Arguments against raising the minimum wage generally focus on the potentially negative employment effects for low-wage workers (see, for example, Neumark, Salas, and Wascher 2013 and 2014).

But one of the main effects of the minimum wage was to increase the bargaining power of workers at non-union firms. Firms with significant monopsony power in the labor market may be able to pay workers significantly less than their marginal (or average) product of labor. This will increase profits and should lead to an increase in the income of executives and shareholders at the top of the income distribution. A minimum wage, along with other institutional labor rules, increases the bargaining power of workers, both those who are earning the minimum wage and those just above.

This bargaining power between workers and executives (or firms) is unobservable but extremely important. While it includes the power of organized labor and collective bargaining, it is by no means limited to union strength and activities. When workers have more bargaining power firms must set higher initial wages, offer larger annual wage and salary increases, and provide better benefits and working conditions in order to keep their workers. When firms have more bargaining power they can demand longer hours for less pay, tell workers there is no 
money for raises, and replace workers more easily. Because those workers at the bottom of the wage distribution are often those with the weakest bargaining power, an increase in the minimum wage can be extremely important for them by making it illegal for firms to push wages as low as they can. While a higher minimum wage may have the effect of increasing income at the bottom of the income distribution and lifting some people out of poverty, it may also reduce the share of income going to the top which is the focus of this paper.

The debate about the effects of the minimum wage on employment are well known, but less well researched is the effect of an increase in the minimum wage on the income share of the top 1 percent or the top 0.1 percent. As Bakija, Cole, and Heim (2010) have shown, executives and managers make up about a third of the top 1 percent. Those in finance make up another 14 percent and these two groups make up about 60 percent of the top 0.1 percent. These groups are likely to benefit when firms are able to increase profits by keeping labor costs low, either through higher executive pay or increased dividends.

The variation in the minimum wage by state allows us to look at the effects of an increase in the real minimum wage on the top 1 percent income share. Currently the highest minimum wage is Washington D.C. $\$ 10.50$ per hour followed by Massachusetts and California at $\$ 10$ while a number of states have no specific minimum wage and employers must meet only the federal minimum. Combined with data on the income distribution from Frank (2009 and 2014) as well as other variables that show the shifting bargaining power between labor and management (and shareholders), we are able to show that the most significant effect of an increase in the minimum wage is not a reduction in the poverty rate, but a reduction in the share of income going to the top 1 percent. We present evidence that increases in the minimum wage reduce the income share of the 1 percent. We provide an interpretation of this distributional 
effect that supports our claim about the effectiveness of the FLSA and the state minimum wage increases.

After a review of the literature on the importance of bargaining power on wages and the effects of the minimum wage in section II, section III presents fixed-effect and Arellano-Bond GMM regressions that look at the effect of the minimum wage on the Gini coefficient, the top 1 percent and top 10 percent income share, the poverty rate, and the income levels for the 10th and 20th percentile households. Section IV concludes and discusses potential policies to reduce income inequality.

\section{The minimum wage in a bargaining power setting}

In the homogenous world of perfect competition, information, and labor mobility there are no economic profits to be had. Workers are all the same and firms are all the same. If a firm will not pay a worker her marginal product of labor, the worker will go to another firm who will. Similarly, if a worker demands more than his marginal product of labor, the firm will hire someone else. There is no bargain to be struck between the worker and the firm in this case as the firm cannot afford to pay more than a worker's marginal product or risk going out of business, and the worker will be unwilling to accept anything less than her marginal product or she will switch jobs.

While the neoclassical model of wage determination is often used in modeling the labor market and thinking about movements of the average wage, it is not as useful when thinking about how the income distribution is determined. Recent macroeconomic modelers have returned to a view of the labor market in which wages are bargained over. Mortensen and Pissarides (1994) assume that each worker-firm match creates a surplus between the value created by the 
job and the worker's reservation wage (based on the value of unemployment benefits). In their model, how the surplus is split is exogenous. When they calibrate the model, they assume the Nash bargaining parameter ( $\beta$ ) to be 0.5 so that the surplus is split evenly between the worker and firm.

Piketty, Saez, and Stancheva (2014) believe that top marginal tax rates affect the relative bargaining position, through what they refer to as the bargaining elasticity, or $e_{3}$ in their model, between workers and executives and show that top income shares shrink as the top marginal tax rate increases. Malloy (2015) takes this one step further and suggests that lower top marginal tax rates, falling unionization rates, and increasing imports all reduce the income growth of the bottom 90 percent of the income distribution, presumably by decreasing labor's bargaining power.

There is increasing work done both on the institutional side of economics and within sociology that labor's declining bargaining power is one of the main explanations for increasing income inequality. Ellis and Smith (2007) and Bental and Demougin (2010) believe that the increased ability of the firm to monitor its workers has decreased the need for efficiency wages and thus reduced labor's bargaining power. Kristal (2010 and 2013) focuses on the zero sum game of how the surplus is split between labor and capital and sees falling unionization, nondefense government spending, "bargaining centralization", and increased trade and computerization as decreasing workers' bargaining power.

As the bargaining power of labor has fallen, that of the top 1 percent has increased. Bivens and Mishel (2013) see the increased income of the top 1 percent as evidence of executives and financial professionals' ability to better capture rents that may have been captured 
more successfully by organized labor in the past. Blanchard and Giavazzi (2003) believe that deregulation in the product and labor markets is likely the cause of this shift in rent capture, but believe that it may equalize again in the long run. Choi and Rios-Rull (2009) show that even in a real business cycle model bargaining over wages can help explain a lower labor share as productivity increases.

There is a more limited literature on the effects of the minimum wage on income inequality. Freeman (1996) looks at the potential positives and negatives of using the minimum wage as a redistributive tool while Flinn (2006) presents a theoretical model showing that a higher minimum wage can be welfare improving. DiNardo, Fortin, and Lemieux (1996), Lee (1999), and Autor, Manning, and Smith (2014) all look at the effects of the minimum wage on lower incomes, typically the ratio of the median income to the income at the $10^{\text {th }}$ percentile. They all find that the minimum wage does decrease inequality by increasing wages at the bottom, usually around the $10^{\text {th }}$ percentile, although Autor, Manning, and Smith, using an IV estimation technique, find a somewhat lesser effect than the earlier articles.

Our technique is somewhat different in that we test for an effect at the top of the income distribution, something Lee (1999) and Autor, Manning, and Smith (2014) believe should not be present in the data and, indeed, something that may represent bias in the regression results, leading to their choice of statistical technique. Our view, however, is that an increase in the minimum wage represents an increase in the bargaining power of labor and is therefore likely to show up as a decrease in the share of income going to the top 1 percent, either as managers, executives, or shareholders. This calls into question the assumptions of these earlier papers, and we show a clear relationship between the minimum wage and the top 1 percent income share. 
Once we move away from the assumption of perfect competition to a more realistic picture in which firms are able to earn positive economic profits, workers are heterogeneous and potentially immobile, and there is less than perfect information, there can be a wide range, or surplus, over which wages can be bargained. The minimum a worker will accept will be some type of reservation wage $\left(w_{R}\right)$, dependent on unemployment benefits, other employment options, and the value of leisure. The maximum wage a firm will pay a worker, $w_{\max }$, may be above the worker's marginal product of labor but will be limited by the firm's need to have non-negative profits so as to stay in business (Schneider 2011 reviews the evidence of wages above and below a worker's MPL).

How the surplus between the reservation wage and the maximum wage is split depends on the relative bargaining power of the firm and worker. While union representation is one aspect of bargaining power, when we discuss bargaining power here, we do not just mean the process of collective bargaining. A worker's bargaining power will increase based on education and skills (human capital), the availability of other employment opportunities (including how mobile the worker is), and the institutional setup of the labor market. This last category will include the tax structure, including everything from the top marginal tax rate to the existence of a negative income tax rate such as the Earned Income Tax Credit (EITC) at the bottom of the income distribution, and the existence and value of the minimum wage, both as a wage floor (Autor, Manning, and Smith 2014), and as an anchor in the minds of labor and firms (Falk et al. 2006).

Theoretically, the minimum wage could either increase or decrease a worker's bargaining power or have no effect. If the minimum wage isn't binding, so that it is below the worker's reservation wage (Figure 1a), there will be no effect on either wages or employment. Another possibility is that the maximum wage the firm can pay a worker and still stay in business is 
below the minimum wage (Figure 1b). If this is the case for many workers, the existence of the minimum wage will have large and negative employment effects. Despite the wide ranging debate, the evidence seems to be on the side of only small employment effects from a higher minimum wage, mainly for teenagers and restaurant workers (Neumark, Salas, and Wascher 2013 and 2014, Dube et al. 2010 and Allegretto et al. 2011).

\section{[Figure 1 here]}

On the other hand, the minimum wage could be above the worker's reservation wage, but below the maximum wage (Figure 1c). In this case the existence of a wage floor truncates the bargaining space and will increase the wage paid to at least some of the workers who fall in this category. In this case the minimum wage will be a binding price floor for at least some workers and we could expect to see a mass of workers earning the minimum which is precisely what we see in the data ${ }^{1}$. The fact that there is a non-negligible percentage of workers earning the minimum wage provides direct support for the wage bargaining view of the labor market as opposed to the neo-classical view (which would require a group of workers all coincidentally having $\left.M P L=w_{\min }\right)$.

Both the minimum wage and the EITC are designed to increase incomes and reduce poverty among those who are working. There is some evidence that the EITC is more effective at reducing poverty than is the minimum wage. Card and Kreuger (1995), followed recently by Burkhauser and Sabia (2007), find no effect of increases in the minimum wage on reducing poverty. They recommend an extension of the EITC as the most effective way of reducing the

\footnotetext{
${ }^{1}$ According to the BLS (2014), 4.3 percent of workers earned the minimum wage or below. This was down significantly from a high of 13.4 percent in 1979, implying that the real minimum wage may be falling toward workers' reservation wages.
} 
poverty rate ${ }^{2}$. Dube (2013), however, reviews the mixed evidence and finds a significant effect of the minimum wage on reducing poverty in his own work.

However, these two policies have very different effects on the relative bargaining power of low-wage workers. As already discussed, a minimum wage truncates the bargaining space and increases the wage both for those earning the minimum wage and those just above it (Autor et al 2010) or below (Boeri et al 2010). The EITC, on the other hand, by providing a wage subsidy to low-wage workers paid for by taxpayers, reduces the (market) reservation wage for workers, and therefore is likely to reduce wages for some low-wage workers and reduce labor costs for firms. Perhaps it is not a surprise that it is the anti-poverty measure favored by many executives.

The fact that the EITC is favored over the minimum wage by many executives and shareholders such as Warren Buffett (who is no inequality apologist) (Novack 2015) also supports the idea that these firm representatives recognize the importance of (unobservable) bargaining power for their own compensation. If the firm is able to increase its relative bargaining power and reduce labor costs, there will be more surplus available to pay out as executive compensation or dividends. In terms of the data, this view implies that as labor's overall bargaining power declines, we would expect to see an increasing share of income going to the top 1 percent of the income distribution. The EITC may be a more successful method in reducing the poverty rate (as noted above), but it reduces labor's bargaining power instead of increasing it. Dube (2013), however, argues that the EITC is a complement to the minimum wage in combating poverty.

\footnotetext{
${ }^{2}$ Scholz (1994), Neumark and Wascher (2001), and Hoynes et al. (2006) all find that the EITC is effective in reducing the poverty rate.
} 
Currently, the proposed increase of the minimum wage is supported by the AFL-CIO:

"Raising the minimum wage is a critical and simple way to help repair the underlying weakness in our economy. It would boost consumer spending and increase the purchasing power of millions of low-wage workers, especially in states with the highest percentages of low-wage workers - many of which also have the highest rates of poverty."3

Of course, bargaining power is not something that's observable in the data. Instead we have to look at the variables that we expect will change the relative bargaining power between workers and firms. These variables include union membership, international trade (if offshore production is being used as a substitute for domestic production), the tax structure (Malloy 2015), and, the focus of this paper, the minimum wage. Our hypothesis is that an increase in the minimum wage will decrease the share of income going to the top 1 percent.

This hypothesized relationship is summarized in Figure 2. Bargaining power between labor and firms is unobserved, but depends on unionization rates, top marginal tax rates, growth, and the minimum wage. The outcome of this is how the worker-firm surplus is split with the observed variable being the top 1 percent income share.

[Figure 2 here]

We test the hypothesis that an increase in the minimum wage will reduce the income share going to the top 1 percent below. Our view of the importance of bargaining power in the labor market allows us to formulate two hypotheses that will be tested in the next section:

H1: An increase in the state minimum wage will decrease the level of state income inequality.

\footnotetext{
${ }^{3}$ http://www.aflcio.org/Issues/Jobs-and-Economy/Wages-and-Income/Minimum-Wage
} 
We expect this mainly to happen through a pre-tax redistribution from those at the top of the income distribution to those who are working at low paying jobs. This brings us to our second hypothesis:

H2: An increase in the state minimum wage will reduce the share of income going to the top 1 percent in that state.

We also test for the effect of the minimum wage on the income share going to the top 10 percent, the poverty rate, and the income of those at the $10^{\text {th }}$ and $20^{\text {th }}$ income percentiles. But we have no strong prior views as to the expected effects.

\section{Effects of the Minimum Wage using State-Level Panel Data}

The minimum wage sets a floor for workers' wages. Thus, even when the bargaining power of workers is very weak and that of their employers is strong, firms cannot pay less than the minimum wage. In the case in which the minimum wage is between most workers' reservation wages and their marginal (or average) product of labor, we expect that a higher minimum wage will increase workers' incomes and reduce incomes going to the top, either in the form of executive compensation or owner/shareholder profits/dividends.

In order to measure the effects of the minimum wage, we construct a panel dataset of the 50 states from 1979 to 2009 . Our hypothesis is that the minimum wage represents one factor of the relative bargaining power between labor and management. Other factors we include are unionization levels, top marginal tax rates, and education levels of the work force.

We use the state minimum wage rates for standard workers (as opposed to tipped workers or trainees), from the U.S. Department of Labor, and adjust nominal values using the consumer 
price index for all items. Inequality and education measures come from Frank (2009 and 2014) and include the Gini coefficient and the top 1 percent and top 10 percent income share. Unionization levels by state come from Hirsch et al. 2001 (updated online) and include both private sector and public sector workers. Top marginal tax rates for each state come from Feenberg and Couts (1993, calculated from Taxsim and updated on NBER's web site). Macroeconomic state variables come from the BEA and BLS. Summary statistics for the main variables of interest are presented in Table 1.

[Table 1 here]

There is significant variation in all of the variables over the 31 years and 50 states. The minimum wage (in 2009 dollars) varies from a low of $\$ 5.33$ to a high of $\$ 10.05$. The Gini coefficient (expressed from 0 to 100) ranges from a low of 44.63 to 70.88 with an average of 55.66. Relatedly, the top 1 percent income share has a low of 5.72 percent and a high of 28.24 percent. On the other end of the income distribution, the poverty rate ranges from 2.9 percent to 27.2 percent. Figure 3 provides a scatter plot of the real effective minimum wage in each state from 1979-2009 and the top 1 percent income share. There is a clear negative relationship in the data.

[Figure 3 here]

There are a number of possible econometric techniques to find the relationship between the minimum wage and our variables of interest. We start out with standard fixed-effects regressions:

$$
y_{i t}=a_{i}+b_{1} \log M W_{i t}+b_{2} \text { Union }_{i t}+b_{3} T M T R_{i t}+b_{4} X_{i t}+\varepsilon_{i t}
$$


Where the dependent variable, $y$, varies by state $i$ and year $t$, and includes the Gini coefficient, the top 1 percent and top 10 percent income share, the poverty rate, and the $(\log )$ real income of the $10^{\text {th }}$ and $20^{\text {th }}$ percentiles. Our main independent variables of interest are the log real minimum wage, $\log M W$, union coverage in the state, Union, and the top marginal tax rate, TMTR. We then control for a number of business cycle and growth variables in the vector $X$ which includes the state and national unemployment and growth rates, a national recession dummy, high school and college graduates (from Frank 2009), and the percent of employment in the manufacturing sector.

The fixed-effect regression results are presented in Table $2^{4}$. Column (i) shows that a one percent increase in the real minimum wage is associated with a 0.039 percentage point fall in the Gini coefficient. An increase from the $25^{\text {th }}$ percentile real minimum wage $(\$ 6.15)$ to the $75^{\text {th }}$ percentile (\$7.15) is an increase of approximately 16 percent. Increasing the minimum wage by 16 percent would be associated with a modest decrease in the Gini coefficient of about 0.64 points. Note that union coverage, the top marginal tax rate, and manufacturing employment also significantly reduce state-level inequality.

\section{[Table 2 here]}

Column (ii) suggests that the decrease in inequality is mainly coming from reducing incomes at the top. We see that a one percent increase in the real minimum wage is associated

\footnotetext{
${ }^{4}$ Lee (1999) and Autor, Manning, and Smith (2014) warn against fixed effect regressions in this type of analysis as it potentially leads to upward bias in the estimated coefficients. Autor, Manning, and Smith (2014) use an instrumental variables approach. But the test of their approach (as suggested in Lee (1999) is that it "finds no impact of the minimum wage on the upper tail of the wage distribution." (Autor, Manning, and Smith 2014, p.3). But this conflicts with our hypothesis. We, in fact, expect to see an effect of the minimum wage on the upper tail of the wage distribution, and so must find a different approach. We also use a GMM Arellano-Bond regression as a check on these fixed-effects regressions.
} 
with a 0.026 percentage point decrease in the top 1 percent income share. Again, moving from the $25^{\text {th }}$ percentile to the $75^{\text {th }}$ would be associated with a significant but modest 0.4 percentage point decrease in income share. Of course, moving from the maximum to the minimum, about an 89 percent increase, would be associated with a more than 2 percentage point drop in income share.

President Obama and the Congressional Democrats currently support an increase in the Federal minimum wage from $\$ 7.25$ to $\$ 10.10$, a 39 percent increase, as well as indexing it to inflation. The results in Table 2 suggest that this could decrease state-level Gini coefficients by 1.54 points (on a 100 point scale) and decrease the top 1 percent income share by approximately 1 percentage point.

Interestingly, columns (iii) and (iv) show no significant relationship between the real minimum wage and the top 10 percent income share or the poverty rate. While the coefficient on the minimum wage in column (iv) is negative, it is quite small and statistically insignificant. The real minimum wage does appear to lift the incomes of those within the bottom 10 percent of the income distribution in column (v). But a 1 percent increase in the minimum wage only increases income at the $10^{\text {th }}$ percentile by about 0.1 percent so this appears to be a modest effect. This suggests that the proposed minimum wage increase could increase the real average income at the $10^{\text {th }}$ percentile by almost 4 percent. There is no significant effect of the minimum wage on the $20^{\text {th }}$ percentile income in column (vi).

Union coverage as a percent of total employment is also significant in reducing inequality, both by reducing the top income shares and by reducing poverty. A one percentage point increase in union coverage decreases the top 1 percent and top 10 percent income share by 
0.21 and 0.24 percentage points, respectively. It also reduces the poverty rate by 0.1 percentage points. Given that union coverage ranges from 3.3 percent to almost 40 percent in the 30 years of this data set, this can have a significant effect on inequality and the poverty rate.

The top state marginal tax rate is also associated with lower inequality, mainly by reducing the share of income going to the top 10 percent. This is in contrast to Malloy (2015) which finds the effect of the top federal income tax rate in reducing the top 1 percent income share and increasing growth among the bottom 90 percent of households.

Given that we have 50 states and only a maximum of 31 years, using the GMM method suggested by Arellano and Bond (1991) and implemented by Roodman (2014) for low T high N panels may be appropriate. These regressions are presented in Table 3 . The dependent variable is lagged for two periods and the national variables (growth, unemployment, and recession) are treated as instruments.

[Table 3 here]

We find very similar results using this methodology as with the fixed-effects regression. The effect of the minimum wage on the Gini coefficient and the top 1 percent income share is significant and nearly identical. Here the proposed 39 percent increase in the minimum wage would be associated with a 1.6 point decrease in the Gini coefficient and a 0.84 percentage point decrease in the top 1 percent income share.

We get slight significance on the effect of the minimum wage in reducing the top 10 percent income share, although the statistical and economic significance is slight. In these GMM regressions we lose significance on the minimum wage's effect on the $10^{\text {th }}$ percentile income. 
Again, we do not see a significant effect of the minimum wage on the poverty rate or the $20^{\text {th }}$ percentile average income.

The effects of union coverage and the top marginal tax rate are similar in sign in the Arellano-Bond regressions as in the fixed-effect regressions. While the coefficients on the top marginal tax rate remain significant, the coefficient for union coverage only remains significant in reducing poverty.

While the correlation between the minimum wage and the top 1 percent income share seems robust from the results in Tables 2 and 3, they do not point to causality. It's possible that our wage bargaining hypothesis is incorrect and that the causality actually runs in the opposite direction. This would be more in line with a political economy explanation in which the top 1 percent's political power is proportional to its income share and so those at the top of the income distribution are more successful in keeping wages at the bottom low when they are more powerful ${ }^{5}$.

To try to disentangle cause from effect, we create a dummy variable equal to one in the year in which there is a real increase to the minimum wage. There is also the question of whether we should add a trend variable. In the time frame of our data set there is a clear trend in our main variables of interest. The top 1 percent income share is increasing and unionization rates and real minimum wages are trending down over the 30 years in the data set. While our job is to try to explain these trends, we do feel that including a linear trend variable may help compensate for any omitted variables.

\footnotetext{
${ }^{5}$ It's also possible, of course, that there is some other variable affecting both the minimum wage and the top income share that we have not accounted for.
} 
Tables 4 and 5 first add the linear trend variable (columns (i), (iii), and (v)) and then add the dummy variable for a real minimum wage increase including five lags (columns (ii), (iv), and (vi)). That is, these regressions included a dummy variable for whether there was an increase this year $(\mathrm{t}=0)$, last year $(\mathrm{t}-1)$, all the way back to five years ago $(\mathrm{t}-5)$. Adding the trend variable does not change the results for the minimum wage significantly, although union coverage loses significance for all dependent variables except the poverty rate.

\section{[Table 4 here]}

The lagged dummy variables for a real minimum wage increase may tell an interesting story. When these variables are included, what we seem to see is a labor market that adjusts somewhat slowly over time. The story on inequality in column (ii) is not consistent across specification, although either the value of the minimum wage or the increase is associated with less inequality. The regression results on the top 1 percent income share in column (iv) shows that the value of the real minimum wage has no significant effect, but that an increase reduces the top 1 percent income share significantly over each of the next five years. This result is robust to specification and seems to provide more support for a causal interpretation of a higher minimum wage reducing the top 1 percent income share over time as labor is able to capture more of the surplus.

\section{[Table 5 here]}

Interestingly, when the real minimum wage increase is included, the value of the minimum wage now seems to be successful in reducing poverty (column (vi)), supporting the results found in Dube (2013). But what we see is that some of the decrease in poverty is given 
back over time, perhaps as the labor market adjusts to the higher wages and either hours or employment are reduced.

\section{Conclusion and policy implications}

Workers' bargaining power increased starting in the 1930s with New Deal legislation, including the minimum wage included in the FLSA, and increased in the post-WWII era as unionization increased, top marginal tax rates remained high, and U.S. industry had little competition from abroad. The minimum wage hit a high in terms of real value in 1968, within about five years of what appears to be the turning point for U.S. income inequality.

But after about 1973, workers have felt their bargaining power erode steadily. Global competition began to increase putting high-cost union firms at a disadvantage. The Reagan revolution sharply reduced top marginal tax rates providing more incentive for executives and shareholders to reduce labor costs. Containerization decreased the costs of producing with less expensive offshore labor, further weakening the position of U.S. workers. And the real value of the minimum wage was allowed to erode until it is now more than 30 percent below that 1968 value.

If the country wishes to reverse the income inequality trends of the last 40 years, the policies to do so should be fairly clear. The federal government (and the states) should work to rebalance the relative bargaining power between workers and firms so that the surplus created by worker-firm matches can be split more equitably. This would include increasing the minimum wage, increasing the top marginal tax rates, and making it as easy as possible for workers to exercise their right to organize and bargain collectively. These were the post-WWII policies that allowed the country to enjoy its lowest levels of income inequality in its history, and there is 
increasing evidence that they are the policies needed to reduce the soaring levels of inequality the country is currently experiencing.

However, as the relative economic power of labor declined and that of the top 1 percent increased, so too did the political power shift. This becomes a vicious cycle in which economic resources are translated into political power and policies are put in place that favor the top 1 percent. This can lead to policies that further erode labor's bargaining power, keeping top marginal tax rates low, eroding the value of the real minimum wage, and making it difficult for workers to organize. If this cycle is to stop, the country will have to break the connection between money and political influence by once again controlling political contributions (or even making all campaigns publicly financed), making it easier or even mandatory to vote by making election day a national holiday, and passing a constitutional amendment to break the connection between money and free speech.

\section{References}

Addison, J. T., \& Blackburn, M. L. (1999). Minimum wages and poverty. Industrial and Labor Relations Review, 393-409.

Allegretto, S. A., Dube, A., \& Reich, M. (2011). Do minimum wages really reduce teen employment? Accounting for heterogeneity and selectivity in state panel data. Industrial Relations: A Journal of Economy and Society, 50(2), 205-240.

Arellano, M., \& Bond, S. (1991). Some tests of specification for panel data: Monte Carlo evidence and an application to employment equations. The review of economic studies, 58(2), 277-297.

Autor, D. H., Manning, A., \& Smith, C. L. (2010). The contribution of the minimum wage to US wage inequality over three decades: a reassessment. Tech. rep., National Bureau of Economic Research.

Bakija, J., Cole, A., \& Heim, B. T. (2010). Jobs and income growth of top earners and the causes of changing income inequality: Evidence from US tax return data. Williamstown:

Williams College. 
Bental, B., \& Demougin, D. (2010). Declining labor shares and bargaining power: An institutional explanation. Journal of Macroeconomics, 32(1), 443-456.

Bivens, J., \& Mishel, L. (2013). The pay of corporate executives and financial professionals as evidence of rents in top 1 percent incomes. The Journal of Economic Perspectives, 27(3), $57-77$.

Blanchard, O., \& Giavazzi, F. (2003). Macroeconomic Effects of Regulation and Deregulation in Goods and Labor Markets. The Quarterly Journal of Economics, 118(3), 879-907.

Boeri, T. (2012). Setting the minimum wage. Labour Economics, 19(3), 281-290.

Burkhauser, R. V., \& Sabia, J. J. (2007). The Effectiveness Of Minimum-Wage Increases In Reducing Poverty: Past, Present, And Future. Contemporary Economic Policy, 25(2), 262-281.

Card, D., \& Krueger, A. B. (1995). Myth and measurement. Princeton University Press Princeton, NJ.

Choi, S., \& Rios-Rull, J.-V. (2009). Understanding the dynamics of labor share: The role of noncompetitive factor prices. Annals of Economics and Statistics/Annales $\left.d^{\prime} \wedge{ }^{\prime} E\right\}$ conomie et de Statistique, 251-277.

Dinardo, J., Fortin, N. M., \& Lemieux, T. (1996). Labor market institutions and the distribution of wages, 1973-1992: a semiparametric approach. Econometrica, 64(5), 1001-1044.

Dube, A. (2013). Minimum Wages and the Distribution of Family Income. University of Massachusetts Amherst and IZA. Unpublished working paper. Available at: https://dl. dropboxusercontent. com/u/15038936/Dube \_MinimumWagesFamilyIncomes. pdf.

Dube, A. T. (2010). Minimum Wage Effects Across State Borders: Estimates Using Contiguous Counties. Review of Economics and Statistics, 92(4), 945-964.

Ellis, L., \& Smith, K. (2007). The global upward trend in the profit share.

Falk, A., Fehr, E., \& Zehnder, C. (2006). Fairness perceptions and reservation wages: The behavioral effects of minimum wage laws. The Quarterly Journal of Economics, 13471381.

Feenberg, D., \& Coutts, E. (1993). An introduction to the TAXSIM model. Journal of Policy Analysis and management, 12(1), 189-194.

Flinn, C. J. (2006). Minimum wage effects on labor market outcomes under search, matching, and endogenous contact rates. Econometrica, 74(4), 1013-1062. 
Frank, M. W. (2009). Inequality and growth in the United States: Evidence from a new statelevel panel of income inequality measures. Economic Inquiry, 47(1), 55-68.

Frank, M. W. (2014). A New State-Level Panel of Annual Inequality Measures over the Period 1916-2005. Journal of Business Strategies, 31(1), 241.

Freeman, R. B. (1996). The minimum wage as a redistributive tool. The Economic Journal, 639649.

Hirsch, B. T., Macpherson, D. A., \& Vroman, W. G. (2001). Estimates of union density by State. Monthly Labor Review, 51.

Hoynes, H. W., Page, M. E., \& Stevens, A. H. (2006). Poverty in America: Trends and explanations. The Journal of Economic Perspectives, 47-68.

Kristal, T. (2010). Good Times, Bad Times Postwar Labor's Share of National Income in Capitalist Democracies. American Sociological Review, 75(5), 729-763.

Kristal, T. (2013). The capitalist machine: Computerization, workers' power, and the decline in labor's share within US industries. American Sociological Review, 78(3), 361-389.

Lee, D. S. (1999). Wage inequality in the United States during the 1980s: Rising dispersion or falling minimum wage? Quarterly Journal of Economics, 977-1023.

Linder, M. (1990). Minimum Wage as Industrial Policy: A Forgotten Role, The. J. Legis., 16, 151.

Malloy, L. C. (2015). Do Higher Top Marginal Tax Rates Slow the Income Growth of Workers? Labour, DOI: 10.1111/labr.12073.

Morgan, D. R., \& Kickham, K. (2001). Children in poverty: Do state policies matter? Social science quarterly, 82(3), 478-493.

Mortensen, D. T., \& Pissarides, C. A. (1994). Job creation and job destruction in the theory of unemployment. The review of economic studies, 61(3), 397-415.

Neumark, D., \& Wascher, W. (2001). Using The EITC to Help Poor Families: New Evidence and a Comparison with the Minimum Wage. National Tax Journal, 54(2), 281-318.

Neumark, D., Salas, J., \& Wascher, W. (2013). Revisiting the Minimum Wage-Employment Debate: Throwing Out the Baby with the Bathwater? Tech. rep., National Bureau of Economic Research.

Neumark, D., Salas, J., \& Wascher, W. (2014). More on recent evidence on the effects of minimum wages in the United States. Tech. rep., National Bureau of Economic Research. 
Novack, J. (2015, May). Warren Buffett Wants A Bigger EITC---And So Do Tax Identity Thieves. Forbes(22).

Piketty, T., Saez, E., Stantcheva, S., \& others. (2014). Optimal Taxation of Top Labor Incomes: A Tale of Three Elasticities. American Economic Journal: Economic Policy, 6(1), 230271.

Roodman, D. (2014). xtabond2: Stata module to extend xtabond dynamic panel data estimator. Statistical Software Components.

Schneider, D. (2011). The labor share: A review of theory and evidence. SFB 649 Economic Risk, Discussion Paper 2011, 69.

Scholz, J. K. (1994). The earned income tax credit: Participation, compliance, and antipoverty effectiveness. National tax journal, 63-87. 
Figures

Figure 1: Potential Locations of the Minimum Wage in Worker-Firm Surplus

(a)

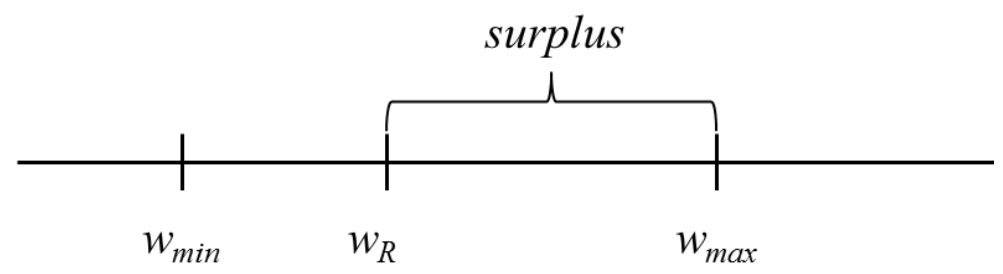

(b)

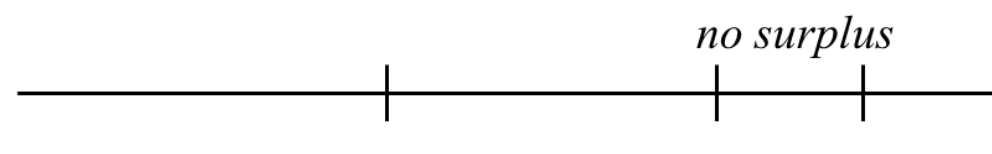

(c)

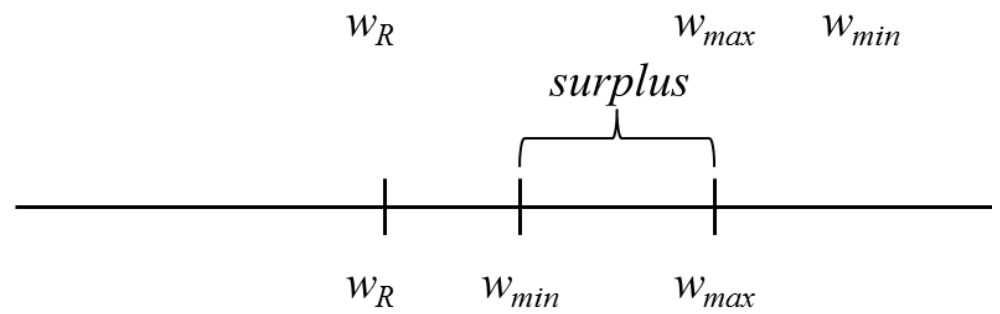

Figure 2: The Minimum Wage and Labor Bargaining Power

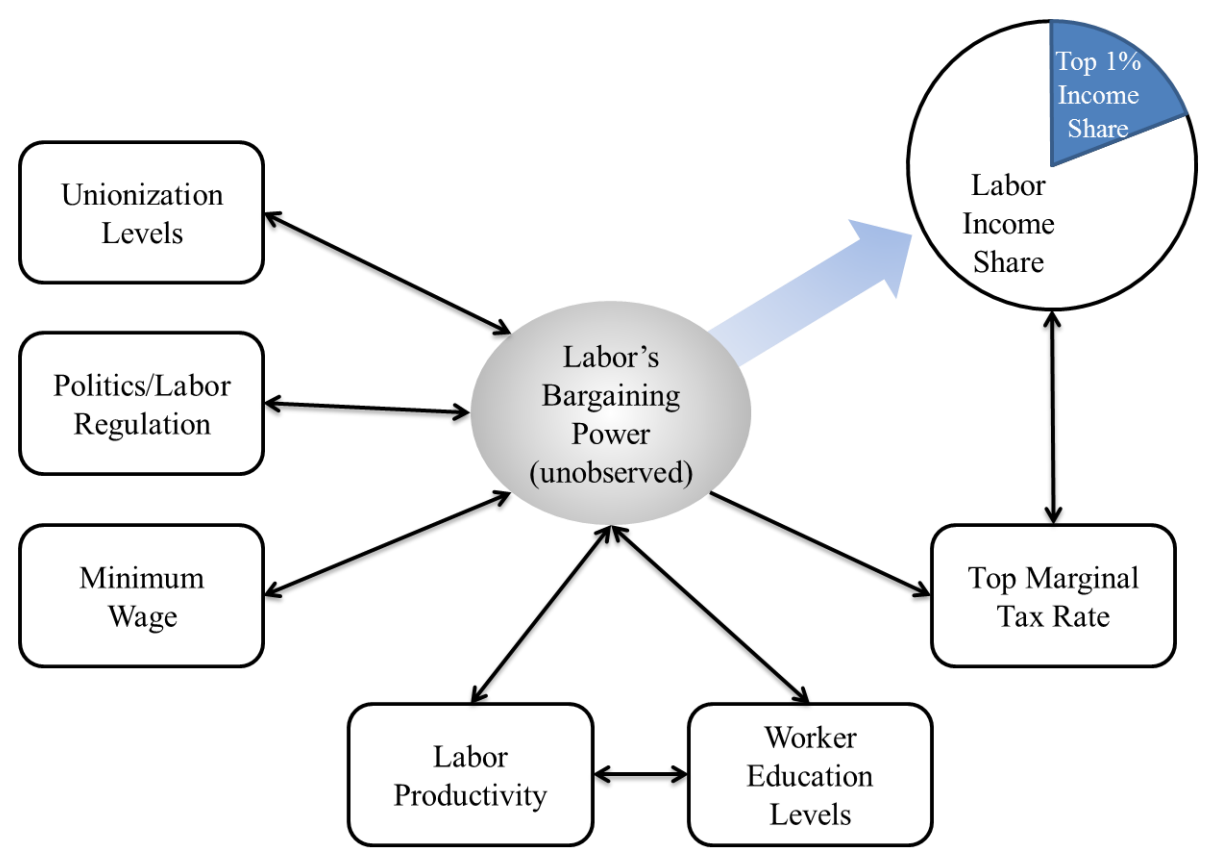


Figure 3: The Minimum Wage vs. Top 1 percent Income Share

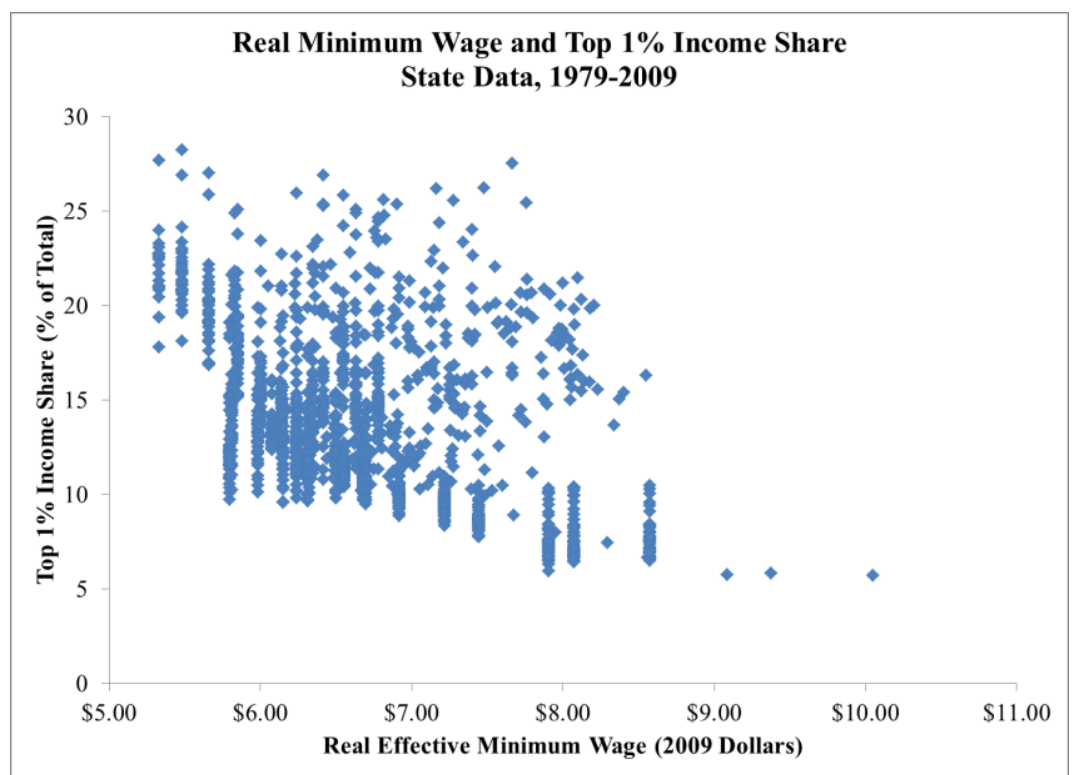

Source: Frank (2009), U.S. Department of Labor 
Tables

Table 1: Summary Statistics

Variable

Real Minimum Wage

(\$2009)

Gini Coefficient

Top 1 percent Income Share

Top 10 percent Income

Share

Union Coverage

Top Marginal Tax Rate

Poverty Rate
Obs

Mean

Std. Dev.

Min

Max

1550

$\$ 6.68$

$\$ 0.76$

$\$ 5.33$

$\$ 10.05$

1550

55.66

4.77

44.63

70.88

1550

13.86

4.29

5.72

28.24

1550

38.28

5.04

28.48

54.63

1550

16.70

7.17

3.30

39.90

1550

43.23

6.89

28.00

58.33

1500

12.89

3.88

2.90

27.20 
Table 2: Fixed Effects Regression of Effects of Real Minimum Wage

\begin{tabular}{|c|c|c|c|c|c|c|}
\hline & (i) & (ii) & (iii) & (iv) & (v) & (vi) \\
\hline & & & & & $(\log ) 10$ & $(\log ) 20$ \\
\hline & & & & & percent & percent \\
\hline & Gini & Top 1 percent & Top 10 percent & Poverty & Percentile & percentile \\
\hline & Coefficient & Income Share & Income Share & Rate & Real Income & Real Income \\
\hline \multirow[t]{2}{*}{ (Log) Real Minimum Wage } & $-3.917 * * *$ & $-2.566 * *$ & 0.445 & -0.293 & $0.106^{* *}$ & 0.0681 \\
\hline & $(1.354)$ & $(1.183)$ & $(1.029)$ & $(0.748)$ & $(0.0497)$ & $(0.0410)$ \\
\hline \multirow[t]{2}{*}{ Union Coverage ( percent Employment) } & $-0.170 * * *$ & $-0.210 * * *$ & $-0.243 * * *$ & $-0.106^{* * *}$ & 0.00320 & $0.00478 * *$ \\
\hline & $(0.0533)$ & $(0.0574)$ & $(0.0607)$ & $(0.0336)$ & $(0.00244)$ & $(0.00201)$ \\
\hline \multirow[t]{2}{*}{ Top Marginal Tax Rate } & $-0.150 * * *$ & -0.0170 & $-0.0653 * * *$ & -0.0172 & -0.000371 & -0.000238 \\
\hline & $(0.0135)$ & $(0.0109)$ & $(0.0105)$ & $(0.0114)$ & $(0.000667)$ & $(0.000553)$ \\
\hline \multirow[t]{2}{*}{ Manufacturing ( percent Employment) } & $-0.396 * * *$ & $-0.196 * *$ & $-0.240 * * *$ & -0.0630 & -0.00265 & $-0.00488^{*}$ \\
\hline & $(0.0911)$ & $(0.0754)$ & $(0.0826)$ & $(0.0524)$ & $(0.00363)$ & $(0.00283)$ \\
\hline \multirow[t]{2}{*}{ High School Graduates ( percent of Pop) } & $0.142 * * *$ & 0.0723 & 0.0516 & $-0.115 * * *$ & -0.00267 & -0.00160 \\
\hline & $(0.0496)$ & $(0.0516)$ & $(0.0592)$ & $(0.0417)$ & $(0.00199)$ & $(0.00165)$ \\
\hline \multirow[t]{2}{*}{ College Graduates ( percent of Pop) } & 0.0134 & $0.387 * * *$ & $0.480 * * *$ & -0.0779 & $0.0143 * * *$ & $0.0132 * * *$ \\
\hline & $(0.0802)$ & $(0.0939)$ & $(0.0811)$ & $(0.0679)$ & $(0.00400)$ & $(0.00332)$ \\
\hline \multirow[t]{2}{*}{ Real State GDP Growth } & $-0.0676^{*}$ & 0.0446 & 0.0503 & 0.0204 & $-0.00306^{* *}$ & $-0.00243 * *$ \\
\hline & $(0.0396)$ & $(0.0300)$ & $(0.0336)$ & $(0.0190)$ & $(0.00138)$ & $(0.00104)$ \\
\hline
\end{tabular}




\begin{tabular}{|c|c|c|c|c|c|c|}
\hline \multirow[t]{2}{*}{ State Unemployment Rate } & 0.00392 & 0.0732 & -0.0368 & $0.647 * * *$ & $-0.0182 * * *$ & $-0.0129 * * *$ \\
\hline & $(0.105)$ & $(0.0994)$ & $(0.0797)$ & $(0.0663)$ & $(0.00601)$ & $(0.00438)$ \\
\hline \multirow[t]{2}{*}{ US Real GDP Growth } & -0.0659 & $-0.0878 *$ & $-0.181 * * *$ & 0.0356 & -0.00247 & -0.00219 \\
\hline & $(0.0438)$ & $(0.0443)$ & $(0.0428)$ & $(0.0398)$ & $(0.00244)$ & $(0.00228)$ \\
\hline \multirow[t]{2}{*}{ US Unemployment Rate } & $-0.239 *$ & $-0.495 * * *$ & $-0.638 * * *$ & -0.0135 & 0.00528 & -0.000477 \\
\hline & $(0.130)$ & $(0.116)$ & $(0.0929)$ & $(0.0788)$ & $(0.00626)$ & $(0.00454)$ \\
\hline \multirow[t]{2}{*}{ US Recession Dummy } & 0.0255 & 0.174 & $-0.346^{* *}$ & -0.170 & -0.00109 & -0.00612 \\
\hline & $(0.156)$ & $(0.157)$ & $(0.149)$ & $(0.198)$ & $(0.0169)$ & $(0.0134)$ \\
\hline \multirow[t]{2}{*}{ Constant } & $71.68 * * *$ & $19.01 * * *$ & $42.48 * * *$ & $19.80 * * *$ & $9.487 * * *$ & $9.965 * * *$ \\
\hline & $(5.178)$ & $(4.197)$ & $(4.529)$ & $(3.133)$ & $(0.194)$ & $(0.157)$ \\
\hline Observations & 1,549 & 1,549 & 1,549 & 1,499 & 1,065 & 1,065 \\
\hline Number of states & 50 & 50 & 50 & 50 & 41 & 41 \\
\hline $\mathrm{R}^{2}$ & 0.84 & 0.79 & 0.90 & 0.83 & 0.75 & 0.83 \\
\hline \multicolumn{7}{|c|}{ Robust standard errors in parentheses } \\
\hline
\end{tabular}


Table 3: Arellano-Bond GMM Regression of Effects of Real Minimum Wage

\begin{tabular}{|c|c|c|c|c|c|c|}
\hline & (i) & (ii) & (iii) & (iv) & (v) & (vi) \\
\hline & & & & & $(\log ) 10$ & $(\log ) 20$ \\
\hline & & & & & percent & percent \\
\hline & Gini & Top 1 percent & Top 10 percent & Poverty & Percentile & percentile \\
\hline & Coefficient & Income Share & Income Share & Rate & Real Income & Real Income \\
\hline \multirow[t]{2}{*}{ (Log) Real Minimum Wage } & $-4.064 * * *$ & $-2.159 * * *$ & $-0.764 *$ & -0.825 & 0.0689 & 0.0412 \\
\hline & $(0.809)$ & $(0.544)$ & $(0.401)$ & $(0.709)$ & $(0.0489)$ & $(0.0411)$ \\
\hline \multirow[t]{2}{*}{ Union Coverage ( percent Employment) } & 0.00863 & -0.0277 & -0.0310 & $-0.0988 * * *$ & 0.00321 & $0.00441 * *$ \\
\hline & $(0.0220)$ & $(0.0221)$ & $(0.0191)$ & $(0.0357)$ & $(0.00252)$ & $(0.00191)$ \\
\hline \multirow[t]{2}{*}{ Top Marginal Tax Rate } & $-0.0512 * * *$ & $0.00983 *$ & $-0.0126 * * *$ & -0.0107 & -0.000660 & -0.000386 \\
\hline & $(0.00496)$ & $(0.00515)$ & $(0.00359)$ & $(0.00922)$ & $(0.000559)$ & $(0.000433)$ \\
\hline \multirow[t]{2}{*}{ Manufacturing ( percent Employment) } & -0.0205 & -0.0200 & 0.0209 & $-0.0837 * *$ & -0.000529 & -0.000203 \\
\hline & $(0.0247)$ & $(0.0177)$ & $(0.0173)$ & $(0.0334)$ & $(0.00238)$ & $(0.00203)$ \\
\hline \multirow[t]{2}{*}{ High School Graduates ( percent of Pop) } & $0.0920 * *$ & $0.227 * * *$ & $0.175^{* * *}$ & -0.0403 & $0.0117 * * *$ & $0.00976^{* * *}$ \\
\hline & $(0.0419)$ & $(0.0313)$ & $(0.0312)$ & $(0.0616)$ & $(0.00394)$ & $(0.00304)$ \\
\hline \multirow[t]{2}{*}{ College Graduates ( percent of Pop) } & $-0.166^{* * *}$ & $-0.0810 * *$ & $-0.0646^{* *}$ & 0.00486 & -0.00387 & $-0.00658^{*}$ \\
\hline & $(0.0392)$ & $(0.0342)$ & $(0.0301)$ & $(0.0452)$ & $(0.00384)$ & $(0.00341)$ \\
\hline \multirow[t]{2}{*}{ Real State GDP Growth } & -0.0181 & $0.0547 * * *$ & $0.0350^{*}$ & -0.00785 & $-0.00211 * *$ & $-0.00151^{*}$ \\
\hline & $(0.0191)$ & $(0.0180)$ & $(0.0183)$ & $(0.0175)$ & $(0.000989)$ & $(0.000810)$ \\
\hline
\end{tabular}




\begin{tabular}{|c|c|c|c|c|c|c|}
\hline \multirow[t]{2}{*}{ State Unemployment Rate } & -0.0651 & 0.0418 & 0.0121 & $0.549 * * *$ & $-0.0102 *$ & $-0.00722 *$ \\
\hline & $(0.0446)$ & $(0.0313)$ & $(0.0243)$ & $(0.0603)$ & $(0.00568)$ & $(0.00403)$ \\
\hline \multirow[t]{2}{*}{ US Real GDP Growth } & -0.0354 & $-0.0497 * *$ & $-0.0735 * * *$ & -0.0184 & 0.00162 & 0.000320 \\
\hline & $(0.0219)$ & $(0.0218)$ & $(0.0205)$ & $(0.0462)$ & $(0.00296)$ & $(0.00271)$ \\
\hline \multirow[t]{2}{*}{ US Unemployment Rate } & 0.00992 & -0.0483 & $-0.117 * * *$ & -0.0273 & 0.00499 & -0.000362 \\
\hline & $(0.0376)$ & $(0.0312)$ & $(0.0329)$ & $(0.0777)$ & $(0.00608)$ & $(0.00437)$ \\
\hline \multirow[t]{2}{*}{ US Recession Dummy } & $-0.799 * * *$ & $-1.034 * * *$ & $-1.220 * * *$ & -0.0709 & 0.0289 & 0.0142 \\
\hline & $(0.121)$ & $(0.156)$ & $(0.132)$ & $(0.205)$ & $(0.0216)$ & $(0.0170)$ \\
\hline \multirow[t]{2}{*}{ Dependent Variable, First Lag } & $0.880 * * *$ & $1.094 * * *$ & $0.973 * * *$ & $0.198 * * *$ & $0.174 * * *$ & $0.175^{* * *}$ \\
\hline & $(0.0363)$ & $(0.0307)$ & $(0.0416)$ & $(0.0306)$ & $(0.0440)$ & $(0.0377)$ \\
\hline \multirow[t]{2}{*}{ Dependent Variable, Second Lag } & $-0.185 * * *$ & $-0.396 * * *$ & $-0.266 * * *$ & 0.0351 & -0.0102 & -0.0174 \\
\hline & $(0.0290)$ & $(0.0329)$ & $(0.0362)$ & $(0.0309)$ & $(0.0410)$ & $(0.0423)$ \\
\hline Observations & 1,398 & 1,398 & 1,398 & 1,348 & 941 & 941 \\
\hline Number of states & 50 & 50 & 50 & 50 & 41 & 41 \\
\hline
\end{tabular}

Robust standard errors in parentheses

$* * * \mathrm{p}<0.01, * * \mathrm{p}<0.05, * \mathrm{p}<0.1$ 
Table 4: Fixed-Effects Regression of Effects of Real Minimum Wage Increases

\begin{tabular}{|c|c|c|c|c|c|c|}
\hline & (i) & (ii) & (iii) & (iv) & (v) & (vi) \\
\hline Dependent Variable: & \multicolumn{2}{|c|}{ Gini Coefficient } & \multicolumn{2}{|c|}{ Top 1 percent Income Share } & \multicolumn{2}{|c|}{ Poverty Rate } \\
\hline \multirow[t]{2}{*}{ (Log) Real Minimum Wage } & $-4.159 * * *$ & $-13.20^{* * *}$ & $-2.997 * * *$ & 2.417 & -0.297 & $-3.607 * *$ \\
\hline & $(1.242)$ & $(2.961)$ & $(1.089)$ & $(2.009)$ & $(0.739)$ & $(1.774)$ \\
\hline \multirow[t]{2}{*}{ Union Coverage ( percent Employment) } & -0.0479 & -0.0576 & 0.0139 & 0.0918 & $-0.113 * * *$ & -0.0664 \\
\hline & $(0.0614)$ & $(0.115)$ & $(0.0340)$ & $(0.0610)$ & $(0.0366)$ & $(0.0500)$ \\
\hline \multirow[t]{2}{*}{ Top Marginal Tax Rate } & $-0.156 * * *$ & $-0.112 * * *$ & $-0.0286 * * *$ & -0.0177 & -0.0168 & 0.0107 \\
\hline & $(0.0121)$ & $(0.0132)$ & $(0.00862)$ & $(0.0109)$ & $(0.0115)$ & $(0.0135)$ \\
\hline \multirow[t]{2}{*}{ Manufacturing ( percent Employment) } & $-0.326 * * *$ & $-0.406 * * *$ & -0.0655 & -0.0473 & -0.0678 & -0.0954 \\
\hline & $(0.0866)$ & $(0.0949)$ & $(0.0642)$ & $(0.0853)$ & $(0.0520)$ & $(0.0605)$ \\
\hline \multirow[t]{2}{*}{ High School Graduates ( percent of Pop) } & 0.0360 & $0.125 * *$ & $-0.122 * *$ & 0.0411 & $-0.109 * *$ & $-0.143 * *$ \\
\hline & $(0.0436)$ & $(0.0530)$ & $(0.0521)$ & $(0.0752)$ & $(0.0417)$ & $(0.0704)$ \\
\hline \multirow[t]{2}{*}{ College Graduates ( percent of Pop) } & $-0.261 * * *$ & $-0.293 * * *$ & -0.117 & $-0.275 * * *$ & -0.0633 & -0.111 \\
\hline & $(0.0897)$ & $(0.0989)$ & $(0.0911)$ & $(0.101)$ & $(0.0832)$ & $(0.0839)$ \\
\hline \multirow[t]{2}{*}{ Real State GDP Growth } & $-0.0750 * *$ & -0.0375 & 0.0310 & $0.0771 * * *$ & 0.0209 & 0.0222 \\
\hline & $(0.0341)$ & $(0.0317)$ & $(0.0255)$ & $(0.0247)$ & $(0.0189)$ & $(0.0199)$ \\
\hline \multirow[t]{2}{*}{ State Unemployment Rate } & 0.00346 & 0.0586 & 0.0722 & 0.0573 & $0.647 * * *$ & $0.720 * * *$ \\
\hline & $(0.1000)$ & $(0.108)$ & $(0.0851)$ & $(0.0980)$ & $(0.0661)$ & $(0.0819)$ \\
\hline \multirow[t]{2}{*}{ US Real GDP Growth } & 0.0326 & -0.00411 & $0.0923 * * *$ & $-0.173 * * *$ & 0.0311 & $0.153^{* *}$ \\
\hline & $(0.0389)$ & $(0.0531)$ & $(0.0309)$ & $(0.0507)$ & $(0.0397)$ & $(0.0653)$ \\
\hline
\end{tabular}




\begin{tabular}{|c|c|c|c|c|c|c|}
\hline \multirow[t]{2}{*}{ US Unemployment Rate } & -0.185 & $-0.256^{* *}$ & $-0.395 * * *$ & $-0.703 * * *$ & -0.0150 & 0.0237 \\
\hline & $(0.122)$ & $(0.127)$ & $(0.101)$ & $(0.111)$ & $(0.0782)$ & $(0.103)$ \\
\hline \multirow[t]{2}{*}{ US Recession Dummy } & $-0.212 *$ & $-0.342 * *$ & $-0.264 *$ & $-1.594 * * *$ & -0.150 & 0.291 \\
\hline & $(0.126)$ & $(0.145)$ & $(0.139)$ & $(0.112)$ & $(0.202)$ & $(0.203)$ \\
\hline \multirow[t]{2}{*}{ Linear Trend } & $0.244 * * *$ & $0.162 *$ & $0.448 * * *$ & $0.470 * * *$ & -0.0134 & 0.00880 \\
\hline & $(0.0560)$ & $(0.0826)$ & $(0.0401)$ & $(0.0406)$ & $(0.0305)$ & $(0.0375)$ \\
\hline \multirow[t]{2}{*}{ Minimum Wage Increase (Dummy) } & & $1.238 * * *$ & & $-0.522 *$ & & $0.644 * * *$ \\
\hline & & $(0.255)$ & & $(0.271)$ & & $(0.177)$ \\
\hline \multirow[t]{2}{*}{ MW Increase (t-1) } & & $0.999 * * *$ & & $-0.470 * *$ & & $0.325^{*}$ \\
\hline & & $(0.194)$ & & $(0.189)$ & & $(0.175)$ \\
\hline \multirow[t]{2}{*}{ MW Increase (t-2) } & & $0.771 * * *$ & & $-0.487 * *$ & & $0.293 * *$ \\
\hline & & $(0.188)$ & & $(0.198)$ & & $(0.140)$ \\
\hline \multirow[t]{2}{*}{ MW Increase (t-3) } & & $0.314 * *$ & & $-1.000 * * *$ & & 0.102 \\
\hline & & $(0.148)$ & & $(0.176)$ & & $(0.152)$ \\
\hline \multirow[t]{2}{*}{ MW Increase (t-4) } & & $-0.374 * *$ & & $-1.111 * * *$ & & $0.268 * *$ \\
\hline & & $(0.146)$ & & $(0.161)$ & & $(0.106)$ \\
\hline \multirow[t]{2}{*}{ MW Increase (t-5) } & & -0.0225 & & $-1.572 * * *$ & & 0.0892 \\
\hline & & $(0.143)$ & & $(0.146)$ & & $(0.134)$ \\
\hline \multirow[t]{2}{*}{ Constant } & $74.49 * * *$ & $87.14 * * *$ & $24.13 * * *$ & 9.260 & $19.70 * * *$ & $25.04 * * *$ \\
\hline & (4.789) & $(8.448)$ & $(5.089)$ & (7.382) & (3.142) & $(5.601)$ \\
\hline Observations & 1,549 & 1,249 & 1,549 & 1,249 & 1,499 & 1,249 \\
\hline Number of states & 50 & 50 & 50 & 50 & 50 & 50 \\
\hline $\mathrm{R}^{2}$ & 0.86 & 0.81 & 0.85 & 0.84 & 0.83 & 0.84 \\
\hline
\end{tabular}


$* * * \mathrm{p}<0.01, * * \mathrm{p}<0.05, * \mathrm{p}<0.1$

Table 5: Arellano-Bond GMM Regression of Effects of Real Minimum Wage Increases

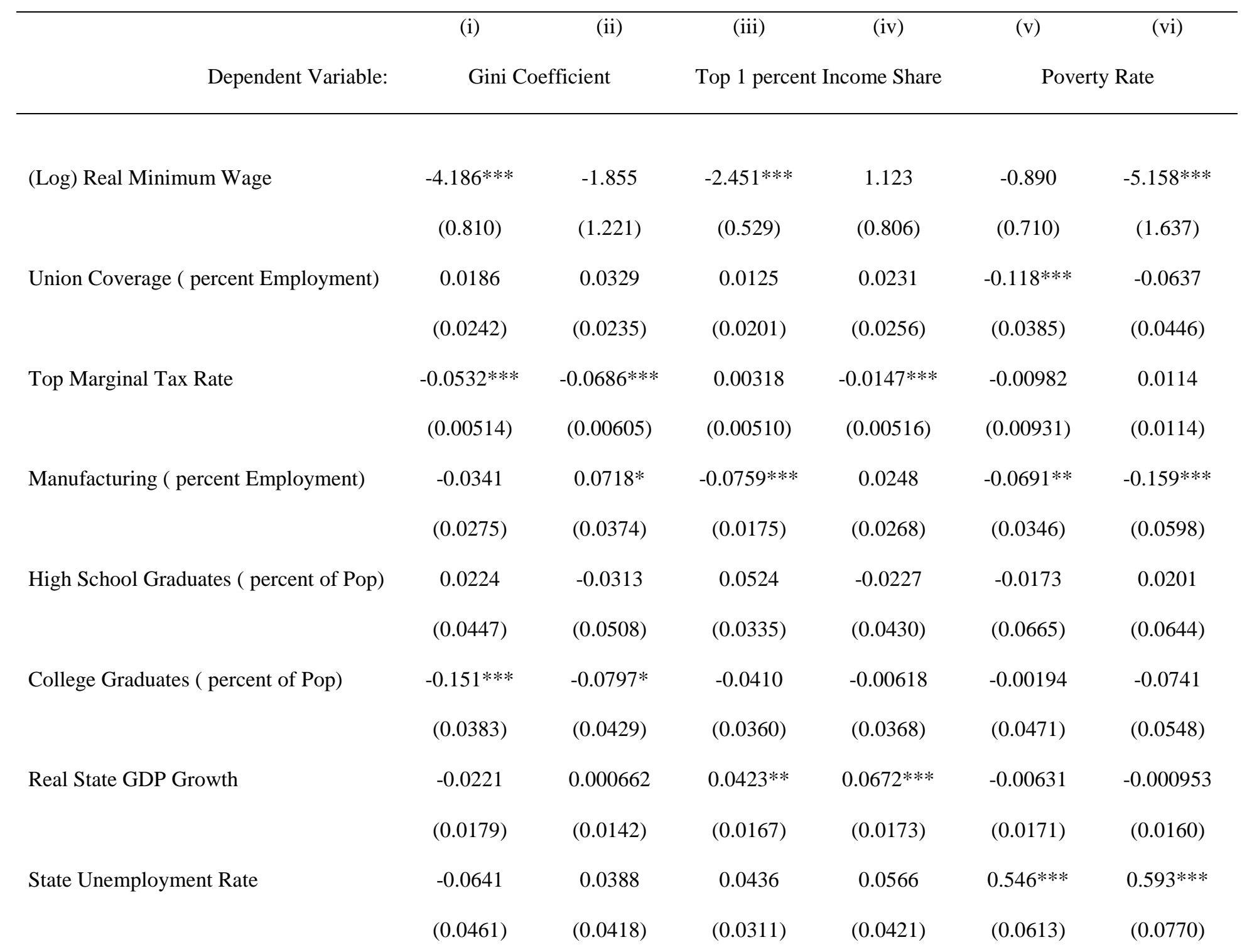




\begin{tabular}{|c|c|c|c|c|c|c|}
\hline \multirow[t]{2}{*}{ US Real GDP Growth } & -0.0309 & 0.0308 & $-0.0387 * *$ & $0.183 * * *$ & -0.0186 & $0.138^{* *}$ \\
\hline & $(0.0218)$ & $(0.0267)$ & $(0.0193)$ & $(0.0343)$ & $(0.0462)$ & $(0.0645)$ \\
\hline \multirow[t]{2}{*}{ US Unemployment Rate } & 0.00589 & $-0.0631^{*}$ & $-0.0905^{* *}$ & -0.0346 & -0.0154 & 0.0637 \\
\hline & $(0.0385)$ & $(0.0351)$ & $(0.0353)$ & $(0.0515)$ & $(0.0775)$ & $(0.0980)$ \\
\hline \multirow[t]{2}{*}{ US Recession Dummy } & $-0.859 * * *$ & $-0.878 * * *$ & $-1.135 * * *$ & $-1.332 * * *$ & 0.00222 & $0.434 *$ \\
\hline & $(0.119)$ & $(0.133)$ & $(0.148)$ & $(0.137)$ & $(0.202)$ & $(0.235)$ \\
\hline \multirow[t]{2}{*}{ Linear Trend } & $0.0467 *$ & 0.0471 & $0.150 * * *$ & $0.170 * * *$ & -0.0244 & -0.00413 \\
\hline & $(0.0280)$ & $(0.0316)$ & $(0.0154)$ & $(0.0143)$ & $(0.0239)$ & $(0.0289)$ \\
\hline \multirow[t]{2}{*}{ Minimum Wage Increase (Dummy) } & & $-0.503^{* * *}$ & & $-0.281 * *$ & & $0.687 * * *$ \\
\hline & & $(0.169)$ & & $(0.111)$ & & $(0.171)$ \\
\hline \multirow[t]{2}{*}{ MW Increase (t-1) } & & 0.161 & & $-0.311 * * *$ & & $0.412 * *$ \\
\hline & & $(0.148)$ & & $(0.0738)$ & & $(0.171)$ \\
\hline \multirow[t]{2}{*}{ MW Increase (t-2) } & & $-0.410 * * *$ & & $-0.408 * * *$ & & $0.322 * *$ \\
\hline & & $(0.117)$ & & $(0.0975)$ & & $(0.137)$ \\
\hline \multirow[t]{2}{*}{ MW Increase (t-3) } & & $-0.294 * * *$ & & $-0.696^{* * *}$ & & 0.136 \\
\hline & & $(0.113)$ & & $(0.101)$ & & $(0.150)$ \\
\hline \multirow[t]{2}{*}{ MW Increase (t-4) } & & $-0.642 * * *$ & & $-0.414 * * *$ & & $0.294 * * *$ \\
\hline & & $(0.104)$ & & $(0.0753)$ & & $(0.102)$ \\
\hline \multirow[t]{2}{*}{ MW Increase (t-5) } & & $0.123 *$ & & $-0.494 * * *$ & & 0.110 \\
\hline & & $(0.0743)$ & & $(0.0917)$ & & $(0.125)$ \\
\hline Dependent Variable, First Lag & $0.871 * * *$ & $0.835 * * *$ & $1.044 * * *$ & $0.891 * * *$ & $0.202 * * *$ & $0.187 * * *$ \\
\hline
\end{tabular}




\begin{tabular}{|c|c|c|c|c|c|c|}
\hline & $(0.0417)$ & $(0.0623)$ & $(0.0335)$ & $(0.0369)$ & $(0.0305)$ & $(0.0315)$ \\
\hline \multirow[t]{2}{*}{ Dependent Variable, Second Lag } & $-0.194 * * *$ & -0.106 & $-0.434 * * *$ & $-0.227 * * *$ & 0.0331 & 0.0428 \\
\hline & $(0.0274)$ & $(0.0664)$ & $(0.0299)$ & $(0.0313)$ & $(0.0311)$ & $(0.0290)$ \\
\hline Observations & 1,398 & 1,198 & 1,398 & 1,198 & 1,348 & 1,198 \\
\hline Number of states & 50 & 50 & 50 & 50 & 50 & 50 \\
\hline
\end{tabular}

Robust standard errors in parentheses

$* * * \mathrm{p}<0.01, * * \mathrm{p}<0.05, * \mathrm{p}<0.1$ 